\title{
STRATEGI PENINGKATAN RETRIBUSI SAMPAH RUMAH TANGGA SEBAGAI SUMBER PENDAPATAN ASLI DAERAH KOTA BEKASI
}

\author{
The Strategies for Increasing Household Waste Retribution as a Source of Bekasi City's \\ Local Revenue
}

\section{Eko Yulianto Widhi Hertomo', Nunung Kusnadi ${ }^{2}$, A. Faroby Falatehan ${ }^{3}$}

\author{
1 Staf Kementerian Keuangan RI. Email: eko.yulianto.001@kemenkeu.go.id \\ 2Staf Pengajar Departemen Agribisnis, Fakultas Ekonomi dan Manajemen. IPB. Email: \\ nunungkusnadi@yahoo.com
}

3Staf Pengajar Departemen Ekonomi Sumberdaya dan Lingkungan, Fakultas Ekonomi dan Manajemen. IPB. Email: f_falatehan@hotmail.com

\begin{abstract}
Bekasi is a city which has a a large population because it lies in the strategic position to support Jakarta city. The higher the population, the more waste it produces. The potential revenue from the household waste retribution as a source of Bekasi city's local revenue will be high and need to be maximized. The objectives of this research were to analyze the contribution of waste retribution in accordance to Bekasi city's local revenue; to estimate the household Willingness to Pay (WTP) in paying the household waste retribution by Contingent Valuation Method (CVM) and factors that affect the WTP; and to determine the hierarchy of strategies for increasing the household waste retribution. The result indicated that the contribution of waste retribution still very low, 1,2 percent in year 2010 and dropped to 0,5 percent in 2016. It was caused by the low tariff in the waste retribution collection system, the lack of quantity and quality of human resources, the low awareness of the community in participating to waste retribution and the lack of facilities in waste services. Based on the CVM analysis, the WTP average for each household is equal to IDR35.000, affected by the house category, frequency of waste transported, and other expense paid together with the waste retribution. The hierarchy of strategies based on AHP method were improvement of facilities and infrastructures, revision of Bekasi waste tariff regulation, improvement of human resources in quantity and quality, dissemination and law enforcement, and incentives in waste reduction.
\end{abstract}

Keywords: Contribution, Retribution, Strategies, Waste, WTP

\begin{abstract}
ABSTRAK
Kota Bekasi adalah kota yang padat penduduk karena terletak di posisi strategis sebagai penyangga kota Jakarta. Semakin padatnya populasi penduduk maka sampah yang dihasilkan semakin banyak. Potensi penerimaan dari retribusi sampah rumah tangga sebagai salah satu komponen Pendapatan Asli Daerah (PAD) kota Bekasi akan tinggi dan perlu ditingkatkan semaksimal mungkin. Tujuan dari penelitian ini adalah untuk menganalisis peran retribusi sampah terhadap PAD kota Bekasi, untuk mengestimasi Willingness to Pay (WTP)/kesediaan rumah tangga dalam membayar retribusi sampah dengan Contingent Valuation Method (CVM) dan menentukan faktor-faktor yang mempengaruhinya, dan menentukan prioritas strategi dalam meningkatkan retribusi sampah rumah tangga di kota Bekasi. Hasil penelitian menunjukkan bahwa kontribusi sampah masih sangat rendah yaitu 1,2 persen pada tahun 2010 dan menurun menjadi 0,5 persen pada tahun 2016. Hal ini diakibatkan oleh rendahnya tarif retribusi dalam sistem pemungutan, rendahnya kuantitas dan kualitas sumber daya manusia (SDM), rendahnya kesadaran dan partisipasi masyarakat dalam membayar retribusi dan rendahnya sarana prasarana pelayanan. Berdasarkan analisis CVM, rata-rata WTP rumah tangga sebesar Rp35.000,00, dipengaruhi oleh kategori rumah, frekuensi sampah diangkut dan biaya lain yang dibayarkan bersamaan dengan pembayaran retribusi sampah. Prioritas strategi berdasarkan metode Analytical Hierarchy Process (AHP) adalah peningkatan sarana dan prasarana, revisi peraturan daerah mengenai struktur tarif retribusi, peningkatan kuantitas dan kualitas SDM, penyuluhan dan penegakan hukum dan insentif pengurangan sampah.
\end{abstract}

Kata Kunci: Kontribusi, Retribusi, Sampah, Strategi, WTP

PENDAHULUAN

Otonomi daerah yang diamanatkan dalam Undang-Undang Nomor 22 Tahun
1999 tentang Pemerintahan Daerah yang berlaku efektif mulai 1 Januari 2001 mempunyai tujuan meningkatkan 
kesejahteraan masyarakat, pelayanan umum dan daya saing daerah. Konsekuensinya, setiap daerah dituntut untuk dapat mandiri dengan mencari penerimaan daerah dan menggali potensi yang ada untuk dapat melaksanakan pembangunan dalam rangka mencapai kesejahteraan masyarakat. Sumber penerimaan daerah tersebut salah satunya berasal dari pendapatan asli daerah (PAD). PAD didapat dari pajak daerah, retribusi daerah, pendapatan lain diluar pajak daerah dan retribusi daerah. Pajak daerah adalah pajak hotel, pajak restoran, pajak hiburan, pajak reklame, pajak parkir dan lain-lain. Retribusi daerah antara lain retribusi pasar, retribusi kebersihan, retribusi ijin usaha industri, retribusi ijin usaha dagang dan lain-lain.

Kota Bekasi adalah kota yang terus berkembang. Laju pertumbuhan penduduk di perkotaan di Indonesia ratarata mencapai 1,78 persen. Menurut Badan Pusat Statistik Jawa Barat, laju pertumbuhan kota Bekasi tahun 20102015 adalah sebesar 3,17 persen sehingga relatif lebih besar dibanding kota lain. Kota Bekasi menjadi tujuan bagi para pencari kerja yang mengakibatkan bertambahnya jumlah penduduk.

Jumlah penduduk yang besar dan tingkat pertumbuhan yang tinggi mengakibatkan bertambahnya volume sampah (Annisa et al. 2015). Laju pertumbuhan penduduk kota Bekasi sejak tahun 2012 sampai dengan 2016 selalu mengalami kenaikan. Diperkirakan jumlah penduduk akan terus meningkat pada tahun-tahun mendatang. Rata-rata laju pertumbuhan penduduk Kota Bekasi sekitar 3,17 persen pertahun dan laju pertambahan jumlah timbulan sampah sekitar 3,17 persen per tahun. Ada korelasi antara peningkatan jumlah penduduk dengan volume sampah. Meningkatnya jumlah penduduk akan menimbulkan masalah sampah, transportasi, permukiman, lingkungan, air, penyakit sosial serta permasalahan tata ruang. Sampah dari aktivitas dan konsumsi masyarakat telah menjadi permasalahan lingkungan yang harus ditangani oleh pemerintah dan masyarakat itu sendiri.

Undang-Undang No. 18 Tahun 2008 tentang Pengelolaan Sampah pada pasal 5 memyebutkan bahwa pemerintah dan pemerintahan daerah bertugas menjamin terselenggaranya pengelolaan sampah yang baik dan berwawasan lingkungan. Sampah dapat sangat bermanfaat jika dikelola dengan baik, oleh karena itu dalam pengelolaaanya diperlukan penanganan yang serius dan biaya yang memadai, salah satunya berupa retribusi yang dibayar oleh masyarakat (Kamalludin 2013). Data pada Badan Pendapatan Daerah Kota Bekasi menunjukkan bahwa retribusi pelayanan kebersihan/persampahan, selanjutnya disebut retribusi sampah, tidak pernah mencapai target penerimaan dan kontribusinya berfluktuasi antara 1,2 persen pada tahun 2010 menjadi 0,5 persen pada tahun 2016.

Berdasarkan hal tersebut, rumusan masalah dalam penelitian ini yaitu: 1) Mengapa kontribusi retribusi sampah kecil dan cenderung menurun?; 2) Berapa potensi ekonomi retribusi sampah perumahan/rumah tangga; dan 3) Bagaimana rumusan strategi peningkatan retribusi sampah sebagai sumber PAD di Kota Bekasi?

Mengacu pada rumusan masalah tersebut, maka tujuan penelitian ini adalah untuk: 1) Mendeskripsikan peran retribusi sampah terhadap peningkatan Pendapatan Asli Daerah (PAD); 2) Mengestimasi potensi ekonomi retribusi sampah perumahan/rumah tangga di kota Bekasi; serta 3) Merumuskan prioritas strategi dalam upaya peningkatan penerimaan retribusi sampah perumahan/rumah tangga.

\section{METODE PENELITIAN}

Data yang digunakan adalah data primer dan data sekunder. Data primer diperoleh melalui penyebaran kuesioner di lapangan serta dilengkapi dengan pengamatan langsung mengenai kondisi 
empirik lokasi penelitian. Penyebaran kuesioner dilakukan terhadap kepala rumah tangga yang membayar retribusi sampah sebanyak 120 responden. Pengambilan sampel metode Willingness to Pay (WTP) dilakukan dengan accidental sampling yaitu dipilih berdasarkan kesediaan calon responden dan kemudahan untuk mendapatkannya. Sedangkan untuk perumusan prioritas strategi dengan AHP dilakukan melalui wawancara pada Bapenda, Dinas Lingkungan Hidup, DPRD dan tokoh masyarakat. Data sekunder diperoleh melalui penelusuran berbagai referensi berupa peraturan perundang-undangan yang mengatur tentang retribusi sampah kota Bekasi. Selain itu, data yang digunakan bersumber dari Bappeda, Bapenda, Dinas Lingkungan Hidup, dan BPS.

Analisis peran retribusi sampah terhadap peningkatan PAD dilakukan dengan menggunakan rasio kontribusi dan analisis deskriptif. Metode tersebut digunakan untuk menganalisis tingkat kontribusi retribusi sampah terhadap peningkatan PAD. Analisis ini dirumuskan sebagai berikut (Yasniva et al. 2016):

Keterangan:

$$
P n=\frac{R X n}{R Y n} \times 100 \%
$$

$\mathrm{P} \quad$ : Kontribusi retribusi sampah

RX : Realisasi penerimaan retribusi sampah

RY : Realisasi PAD

$\mathrm{n}$ : Tahun tertentu

Dengan dilakukan perhitungan kontribusi maka dapat diketahui berapa besar kontribusi yang diberikan retribusi sampah terhadap PAD kota Bekasi sesuai dengan kriteria pada tabel 1.
Tabel 1 Kriteria Kontribusi

\begin{tabular}{cc}
\hline Persentase & Kriteria \\
\hline $0 \%-10 \%$ & Sangat kurang \\
$10 \%-20 \%$ & Kurang \\
$20 \%-30 \%$ & Sedang \\
$30 \%-40 \%$ & Cukup baik \\
$40 \%-50 \%$ & Baik \\
Di atas 50\% & Sangat baik \\
\hline
\end{tabular}

Sumber : (Halim 2004)

Estimasi terhadap nilai WTP dilakukan dengan menggunakan pendekatan Contingent Valuation Method (CVM) yang dilakukan terhadap 120 responden yang membayar retribusi sampah rumah tangga. Metode CVM dilakukan dengan menghitung nilai ratarata WTP dan selanjutnya mengestimasikan total WTP terhadap data terakhir jumlah rumah tangga untuk memperoleh potensi penerimaan retribusi sampah rumah tangga. Selanjutnya dilakukan analisis terhadap faktor-faktor yang mempengaruhi nilai WTP retribusi sampah rumah tangga di kota Bekasi dengan menggunakan model regresi. Model penelitian yang digunakan yaitu sebagai berikut:

$$
\begin{aligned}
L n_{-} W T P=\beta_{0} & +\beta_{1} K R+\beta_{2} L n_{-} T P \\
& +\beta_{3} F A+\beta_{4} L n_{-} B L+\varepsilon
\end{aligned}
$$

Dimana:

Ln_WTP : Nilai WTP responden (rupiah)

$$
\begin{array}{ll}
\beta_{0} & : \text { Konstanta } \\
\beta_{1}, \ldots, \beta_{4} & : \text { Koefisien regresi } \\
\text { KR } & : \text { Kategori rumah (1=rumah } \\
& \text { tangga non } \\
& \text { perumahan/kampung, } \\
& \text { 2=rumah di perumahan } \\
& \text { sederhana, 3=rumah di } \\
& \text { perumahan menengah, } \\
& \text { 4=rumah di perumahan } \\
& \text { mewah) }
\end{array}
$$

Ln_TP : Tingkat pendapatan (rupiah)

FA : Frekuensi sampah diangkut (hari sekali)

Ln_BL : Biaya lain yang dipungut bersamaan dengan retribusi sampah (rupiah)

$\varepsilon \quad$ : error term 
Pemilihan prioritas strategi digunakan metode Analytical Hierarchy Process (AHP). Analisis ini dilakukan dengan menangkap secara rasional persepsi orang yang berhubungan erat dengan permasalahan tertentu melalui prosedur yang didesain untuk sampai pada skala preferensi di antara berbagai set alternatif (Falatehan 2016). Pemilihan prioritas strategi dilakukan dengan cara pengumpulan data expert judgements dari empat orang ahli yaitu pejabat Bapenda, pejabat Dinas Lingkungan Hidup, sekretaris komisi C DPRD Kota Bekasi dan tokoh masyarakat.

\section{HASIL DAN PEMBAHASAN}

\section{Peran Retribusi Sampah Terhadap Peningkatan PAD}

Tingkat kontribusi retribusi sampah rumah tangga terhadap PAD kota Bekasi selama tahun 2010-2016 masih relatif rendah dan berfluktuasi yaitu 1,2 persen pada tahun 2010 dan 0,5 persen pada tahun 2016. Kontribusi tertinggi terjadi pada tahun 2010 yaitu sebesar 1,2 persen dan terendah terjadi tahun 2015 yaitu sebesar 0,4 persen. Rata-rata kontribusi sebesar 0,7 persen. Persentase kontribusi pada kisaran 0 sampai dengan 10 persen menunjukkan bahwa kriteria kontribusi masuk ke dalam kriteria sangat kurang. Nilai kontribusi yang rendah menunjukkan bahwa retribusi sampah belum mampu menjadi komponen utama dalam mendorong peningkatan PAD di kota Bekasi. Kondisi tersebut memacu pemerintah daerah untuk terus menggali dan mengoptimalkan pemanfaatan potensi retribusi sampah agar penerimaan retribusi sampah dapat terus ditingkatkan. Diharapkan ke depannya retribusi sampah termasuk dari sampah rumah tangga dapat memberikan kontribusi yang lebih besar bagi PAD kota Bekasi. Kontribusi sampah terhadap PAD kota Bekasi dapat dilihat dalam Tabel 2.

\begin{tabular}{|c|c|c|c|}
\hline Tabel & $\begin{array}{l}2 \text { Kontri } \\
\text { terhada] } \\
\text { Tahun } \\
\text { rupiah) }\end{array}$ & $\begin{array}{l}\text { Rusi Retribs } \\
\text { PAD K } \\
010-2016\end{array}$ & $\begin{array}{l}\text { i Sampah } \\
\text { ta Bekasi } \\
\text { lam jutaan }\end{array}$ \\
\hline Tahun & $\begin{array}{c}\text { Realisasi } \\
\text { Retribusi } \\
\text { Sampah }\end{array}$ & PAD & $\begin{array}{c}\text { Kontribusi } \\
(\%)\end{array}$ \\
\hline 2010 & $3.564,47$ & $291.836,75$ & 1,2 \\
\hline 2011 & $4.064,92$ & $568.344,30$ & 0,7 \\
\hline 2012 & $6.118,60$ & $735.485,51$ & 0,8 \\
\hline 2013 & $6.616,79$ & $969.664,34$ & 0,7 \\
\hline 2014 & $6.567,29$ & $1.205 .243,32$ & 0,5 \\
\hline 2015 & $6.373,62$ & $1.504 .509,85$ & 0,4 \\
\hline 2016 & $8.010,57$ & $1.608 .592,11$ & 0,5 \\
\hline & Rata-rata & & 0,7 \\
\hline
\end{tabular}

Sumber : (Bapenda Kota Bekasi)

Melalui Tabel 2 di atas, dapat terlihat bahwa kontribusi retribusi sampah terhadap PAD masih kecil dan justru cenderung menurun. Hal tersebut menunjukkan ada hambatan di dalam mencapai target penerimaan retribusi sampah. Berdasarkan hasil wawancara dari Bapenda dan Dinas Lingkungan Hidup diketahui bahwa terdapat beberapa kendala yang menyebabkan kontribusi dari retribusi sampah terutama sampah rumah tangga kecil dan bahkan tidak pernah mencapai target yaitu:

1. Sistem pemungutan dan tarif:

a. Sistem pemungutan retribusi sampah dilakukan dengan memungut dari pengurus lingkungan. Dana tersebut diambil oleh petugas tetapi tidak ada bukti pembayaran dari warga. Dana ini memungkinkan tidak disetor ke kas daerah. Petugas di lapangan mengeluarkan hasil penyetoran retribusi sampah untuk perbaikan truk, penggantian spare part kendaraan, kecelakaan di jalan, dan lain-lain.

b. Pemungutan retribusi sampah tidak sesuai dengan peraturan daerah (Perda). Retribusi sampah rumah 
tangga diatur sesuai luas bangunan rumah. Namun, besaran retribusi yang dipungut adalah hasil negosiasi pemerintah daerah dengan pengurus lingkungan. Besaran retribusi adalah bagian dari dana yang dipungut pengurus lingkungan untuk dana keamanan. Rendahnya tarif retribusi sampah dalam Perda menyebabkan rendahnya penerimaan retribusi.

2. Jumlah SDM masih terbatas dalam segi kuantitas maupun kualitas dalam melakukan pelayanan dan memungut retribusi masih. Petugas masih banyak yang statusnya kontrak ataupun tenaga harian lepas.

3. Masih banyak warga masyarakat yang memiliki kesadaran rendah akan pentingnya kebersihan dan kesehatan serta retribusi sampah dengan membuang sampah secara liar. Hal ini juga disebabkan lemahnya penegakan hukum terhadap pelaku pembuang sampah liar.

4. Pada proses pengumpulan dan pengangkutan sampah, sarana dan prasarana yang dimaksudkan misalnya bak/tempat sampah, sementara pada proses pengangkutan, armada angkutan sampah beserta kemampuan daya angkut masing-masing jenis armada. Informasi mengenai hal ini dipandang penting mengingat jumlah dan kapasitas armada angkut akan menentukan berapa banyak sampah yang bisa terangkut ke TPS dan titik komunal lainnya ke Tempat Pembuangan Akhir (TPA). Sementara pada proses pengolahan sampah, sarana dan prasarana yang dimaksudkan adalah jumlah TPS dan TPA berikut luasan dan kapasitasnya (Tasrin dan Shafiera 2014). Yang menjadi kendala antara lain:

a. Jumlah sarana pengangkut dan peralatan belum memadai sehingga pemerintah kota Bekasi mengalami keterbatasan dalam melakukan pelayanan. Pelayanan yang dinilai tidak memuaskan akan membuat masyarakat enggan membayar retribusi.

b. Sarana Tempat Pembuangan Akhir (TPA) Sumur Batu sudah hampir penuh. Pelayanan persampahan melihat kondisi TPA. Ketika sudah mencapai batas, sampah yang tadinya diambil sehari sekali bisa menjadi 3 hari sekali. Hal ini dapat menyebabkan masyarakat menilai pelayanan kurang bagus.

c. Tidak semua rumah dapat dijangkau oleh petugas. Untuk pemukiman tidak teratur sering tidak dapat dijangkau oleh petugas yang jumlahnya terbatas dengan sarana yang terbatas.

d. Keterbatasan sarana dan prasarana menyebabkan munculnya pihak swasta yang melakukan pelayanan persampahan dan memungut retribusi sampah tetapi tidak bekerjasama dengan pemerintah daerah. Masyarakat menilai pelayanan swasta lebih baik dalam hal frekuensi pengambilan sampah. Pihak swasta yang tidak bekerjasama dengan pemerintah tidak menyetor dana retribusi kepada pemerintah daerah. Tidak adanya kerja sama memungkinkan pembuangan sampah dilakukan secara liar atau justru bekerja sama dengan daerah tetangga yaitu kabupaten Bekasi, Bogor, dan Depok.

\section{Potensi Ekonomi Berdasarkan \\ Estimasi Nilai WTP dan Faktor yang Mempengaruhinya}

\section{Estimasi Nilai WTP}

Willingness to Pay (WTP) rumah tangga berpengaruh signifikan terhadap penerimaan retribusi sampah. Hal ini disebabkan karena semakin tingginya kemampuan membayar masyarakat terhadap retribusi sampah, maka kerelaan masyarakat untuk membayarnya akan muncul sehingga penerimaan retribusi sampah juga akan meningkat (Jaya et al. 2014). Analisis WTP dilakukan dengan 
menggunakan metode CVM terhadap 120 responden yang membayar retribusi sampah rumah tangga. Berdasarkan hasil analisis diperoleh rata-rata nilai WTP sebesar Rp35.000 per rumah tangga. Apabila disimulasikan dengan data BPS Jawa Barat tahun 2014 yang menunjukkan jumlah rumah tangga sebanyak 682.878, maka diperoleh potensi ekonomi sesuai nilai estimasi WTP sebesar Rp23,9 miliar per bulan atau Rp286,8 miliar per tahun. Sementara itu, data Bapenda menunjukkan pendapatan dari retribusi sampah rumah tangga tahun 2016 sebesar Rp6,567 miliar.

\section{Analisis Faktor-Faktor yang Mempengaruhi Nilai WTP}

Hasil estimasi terhadap faktorfaktor yang mempengaruhi nilai WTP retribusi sampah rumah tangga kota Bekasi secara lengkap disajikan padaTabel 3.

Tabel 3 Hasil Estimasi Faktor-faktor yang Mempengaruhi Nilai WTP

\begin{tabular}{lccc}
\hline Source & Value & Standard error & \multicolumn{1}{c}{ Sig } \\
\hline Intercept & 5,765 & 1,148 & 0,0000 \\
KR & 0,283 & 0,048 & $0,0000^{*}$ \\
Ln_TP & 0,089 & 0,068 & 0,1928 \\
FA & $-0,110$ & 0,027 & $0,0000^{*}$ \\
Ln_BL & 0,268 & 0,059 & $0,0000^{*}$ \\
\hline $\mathrm{R}^{2}$ & & & 0,712 \\
Adjusted R & & & 0,702 \\
Prob (F Statistik) & & & 0,000 \\
\hline Keterangan:
\end{tabular}

Keterangan: *signifikan pada $\alpha=5$ persen

Sumber: Data survei diolah (2017)

Hipotesis:

H1 : Kategori rumah (KR) berpengaruh positif terhadap besaran retribusi sampah rumah tangga.

H2 : Tingkat pendapatan (TP) berpengaruh positif terhadap besaran retribusi sampah rumah tangga.

H3 : Frekuensi sampah diangkut (FA) berpengaruh negatif terhadap besaran retribusi sampah rumah tangga.

H4 : Biaya lain (BL) berpengaruh positif terhadap besaran retribusi sampah rumah tangga.

Berdasarkan Tabel 1, nilai WTP diduga dipengaruhi oleh KR, TP, FA, dan BL. Namun, berdasarkan hasil analisis regresi linear berganda menunjukkan bahwa variabel KR, FA dan Ln_BL berpengaruh nyata terhadap nilai WTP pada alpha 5 persen. Sedangkan variabel Ln_TP tidak berpengaruh nyata terhadap WTP.

Variabel KR dan Ln_BL berpengaruh positif terhadap WTP dengan masing-masing koefisien 0,283 dan 0,268. Hal ini berarti, pergeseran KR 1 tingkat akan meningkatkan WTP sebesar 0,283 persen dan peningkatan
Ln_BL sebesar 1 persen maka akan meningkatkan WTP sebesar 0,268 persen. Sedangkan untuk variabel FA berpengaruh negatif terhadap WTP dengan koefisien 0,110 yang berarti penambahan FA 1 hari akan menurunkan WTP sebesar 0,110 persen. Model pada penelitian ini memiliki nilai Adjusted $R$ square sebesar 0,702 atau 70,2 persen artinya keragaman WTP dapat dijelaskan oleh variabel-variabel dalam model dan sisanya 29,8 persen dijelaskan oleh variabel lain di luar model. Variabel bebas secara keseluruhan menunjukkan nilai probabilitas sebesar 0,000 artinya 
bahwa tolak $\mathrm{H} 0$ atau minimal terdapat variabel bebas yang berpengaruh terhadapa WTP dan dapat disimpulkan bahwa secara simultan variabel bebas berpengaruh terhadap WTP.

\section{Prioritas Strategi Peningkatan Retribusi Sampah Rumah Tangga Kota Bekasi}

Bobot prioritas masing-masing level hirarki dari AHP secara lengkap disajikan pada Gambar 1. Untuk level faktor berdasarkan tujuan peningkatan retribusi sampah rumah tangga kota Bekasi, diperoleh urutan pertama yaitu sistem pemungutan dengan bobot sebesar 0,492. Faktor penting selanjutnya berturut-turut adalah sumber daya manusia dengan bobot sebesar 0,311 dan anggaran dengan bobot sebesar 0,197. Sistem pemungutan dinilai sebagai prioritas pertama dibandingkan faktor lainnya dikarenakan sistem pemungutan retribusi sampah rumah tangga kota Bekasi merupakan kunci utama dalam menentukan keberhasilan peningkatan retribusi sampah rumah tangga.

Perbandingan antara elemen aktor berdasarkan faktor diperoleh hasil dengan urutan pertama yaitu Badan Pendapatan Daerah (Bapenda) dengan bobot sebesar 0,371, Dinas Lingkungan Hidup dengan bobot sebesar 0,354, Dewan Perwakilan Rakyat Daerah (DPRD) dengan bobot sebesar 0,152 dan masyarakat dengan bobot sebesar 0,200. Bapenda menduduki urutan pertama karena Bapenda merupakan pihak yang memiliki kewenangan untuk merumuskan kebijakan terkait peningkatan retribusi sampah rumah tangga kota Bekasi.

Perbandingan antara kendala berdasarkan aktor, urutan pertama adalah tarif retribusi sampah yang rendah dengan bobot sebesar 0,300. Hal tersebut dikarenakan tarif retribusi sampah sudah cukup lama berlaku yaitu tahun 2005 melalui Peraturan Daerah (Perda) Kota Bekasi Nomor 07 Tahun 2005 tentang Retribusi Pelayanan Kebersihan. Pada tahun 2012 melalui Perda Nomor 09
Tahun 2012 tentang Retribusi Daerah tarif tersebut tidak diperbaharui untuk menyesuaikan dengan kondisi yang ada. Menurut Sjafrizal (2008: 250) pada dasarnya salah satu upaya utama yang dapat dilakukan dalam rangka meningkatkan Pendapatan Asli Daerah (PAD) suatu daerah, yaitu dengan penyesuaian tarif pajak dan restribusi daerah sesuai dengan harga dan perkembangan tingkat inflasi. Untuk urutan kendala selanjutnya secara berurutan adalah keterbatasan sarana dan prasarana dengan bobot sebesar 0,284, keterbatasan sumber daya manusia (SDM) baik dari segi kuantitas maupun kualitas dengan bobot sebesar 0,215 dan rendahnya partisipasi dan kesadaran masyarakat dengan bobot sebesar 0,200.

Perbandingan antara elemen prioritas strategi berdasarkan kendala maka urutan prioritas strategi yang dihasilkan dalam upaya peningkatan retribusi sampah rumah tangga sebagai sumber PAD kota Bekasi, yaitu: 1) Meningkatkan sarana dan prasarana dengan bobot sebesar 0,232 ; 2) Revisi Perda mengenai struktur tarif dengan bobot sebesar 0,200; 3) Meningkatkan kinerja SDM dengan bobot sebesar 0,199; 4) Penyuluhan dan penegakan hukum dengan bobot sebesar 0,192; 5) Insentif dan disinsentif pengurangan sampah dengan bobot sebesar 0,176 .

Implementasi dari beberapa strategi peningkatan retribusi sampah rumah tangga sebagai sumber PAD kota Bekasi sesuai dengan prioritas hasil AHP disajikan dalam lampiran 1 .

a. Meningkatkan sarana dan prasarana

Peningkatan prasarana dan sarana sejalan dengan faktor yang mempengaruhi peningkatan retribusi sampah rumah tangga di kota Bekasi, yaitu sistem pemungutan dan anggaran. Dalam kapasitas kota sebagai sumber pemenuhan kebutuhan manusia maka sudah seyogyanya untuk menyediakan berbagai sarana dan prasarana yang memadai dalam menjaga kelestarian 
lingkungan melalui pengelolaan persampahan yang baik (Rizal 2011). Dengan sistem pemungutan yang saat ini berjalan, dimungkinkan terjadi kebocoran dalam pemungutan retribusi sampah. Pengurus RT/RW yang melakukan penyetoran retribusi sampah kepada petugas Dinas Lingkungan Hidup dan Bapenda tidak mendapatkan karcis atau tanda bukti lain. Strategi yang dapat dilakukan adalah dengan mencontoh daerah lain yang menarik retribusi sampah bersamaan dengan pembayaran iuran kepada PLN atau PAM. Penyediaan sarana berupa sistem pembayaran secara online juga dapat dilakukan. Penyusunan database wajib retribusi secara detail dapat dibuat untuk mendukung sistem pembayaran online tersebut.

Tujuan

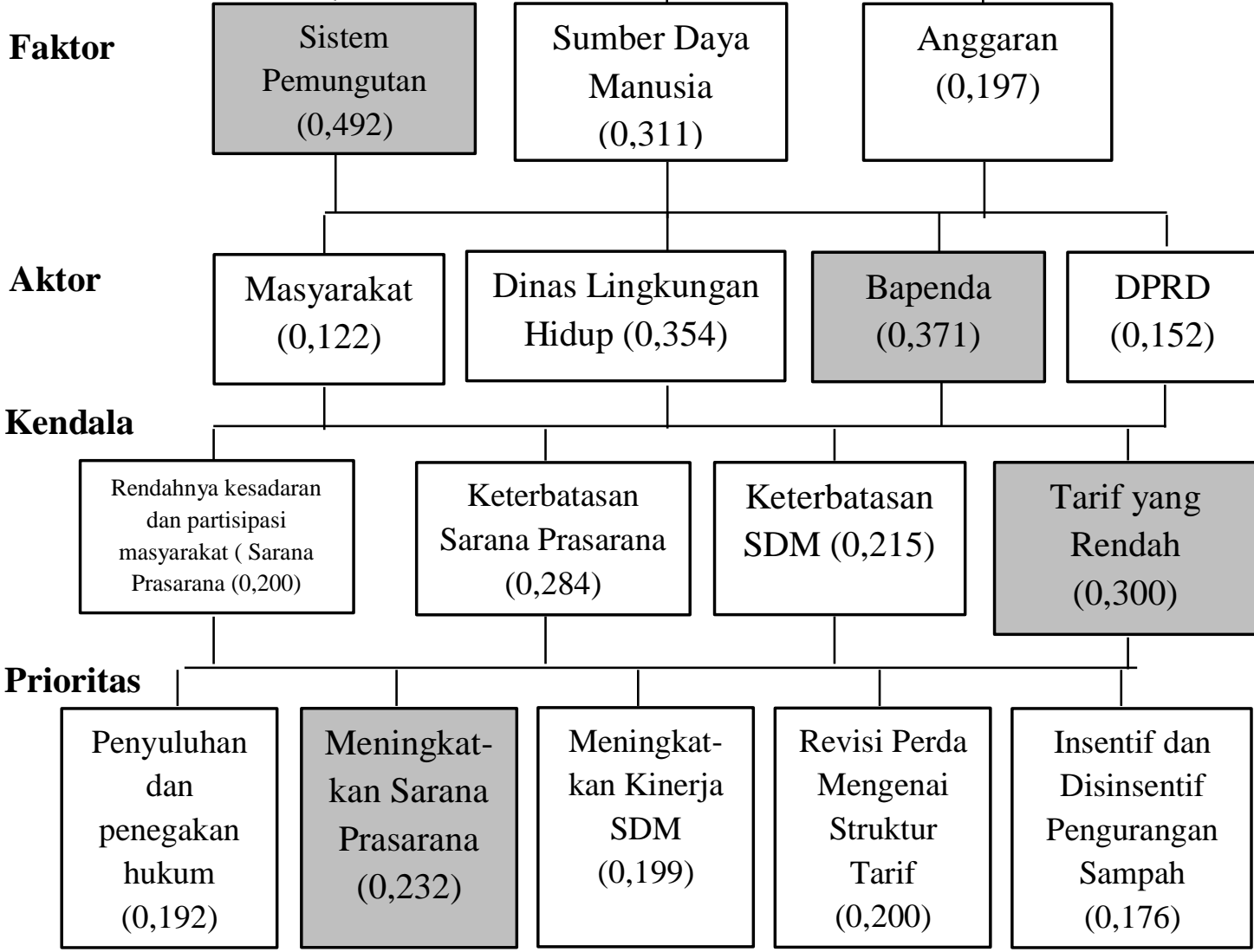

Gambar 1 Struktur dan Nilai Bobot Hirarki Strategi Peningkatan Retribusi Sampah Rumah Tangga Kota Bekasi

b. Meningkatkan kinerja SDM

Pelaksanaan pelayanan persampahan terkait erat dengan personil yang melaksanakannya. Pengembangan SDM perlu dilakukan sehingga bisa sesuai dengan pengelolaan sampah yang direncanakan. Pelatihan persampahan terkait dengan masalah lingkungan. Perlu juga diberikan insentif dan dilakukan pengawasan serta pembinaan agar SDM mampu menghasilkan kinerja yang diharapkan.

c. Penyuluhan dan penegakan hukum

Pengelolaan persampahan suatu daerah sangat ditentukan oleh peraturan yang mendukungnya. Peraturan-peraturan tersebut melibatkan wewenang dan tanggung jawab pengelola kebersihan serta partisipasi masyarakat dalam 
menjaga kebersihan dan pembayaran retribusi (Rizal 2011). Masyarakat sebagai penghasil sampah perlu ditingkatkan kesadarannya melalui pendidikan formal maupun informal. Peran serta masyarakat yang baik hanya dapat dicapai bila sistem yang tersedia sudah baik. Hal ini merupakan hubungan timbal balik yang saling mempengaruhi apabila sarana fisik dan peralatan maupun kegiatan non fisik berupa penyuluhan, pengawasan, pemantauan dan peraturan berjalan dengan baik secara profesional, tidak hanya kuantitatif saja. Penyuluhan yang dapat dilakukan adalah mengenai pembayaran retribusi secara rutin sesuai dengan peraturan yang berlaku dan pemilahan sampah oleh masyarakat dari sumbernya baik rumah, kantor, RT/RW, kelurahan dan kecamatan.

d. Insentif dan disinsentif pengurangan sampah

Kendala terbatasnya anggaran pemerintah daerah dalam membangun sarana dan prasarana permukiman termasuk dalam pengelolaan persampahan menyebabkan pemerintah harus memaksimalkan upaya yang mendorong badan usaha swasta untuk terlibat secara aktif dalam pembangunan dan pengoperasian fasilitas sampah. Pengurangan sampah dilakukan Pemerintah daerah kota Bekasi ditekankan pada pembinaan, monitoring, dan pengawasan terhadap produsen agar produknya tidak menimbulkan banyak timbulan sampah, termasuk terhadap produsen yang melakukan usaha mendaur ulang sampah. Dengan demikian pelaksana pengurangan sampah dilakukan oleh institusi lain (bukan pemerintah). Disini yang dilakukan pemerintah adalah mendorong produsen dalam pengurangan sampah.

Insentif dan insentif pengurangan sampah tertuang dalam pasal 15 dan pasal 16 Peraturan Daerah (Perda) nomor 15 tahun 2011 tentang pengelolaan sampah 90 di kota Bekasi. Pemerintah daerah dapat memberikan insentif kepada setiap orang dan produsen yang melakukan pengurangan sampah berupa potongan retribusi dan insentif lainnya yang kondusif untuk orang dan produsen melakukan pengurangan timbulan sampah. Pemda juga dapat memberikan disinsentif kepada produsen yang tidak melakukan pengurangan sampah berupa denda.

\section{KESIMPULAN}

Berdasarkan Berdasarkan hasil analisis yang dilakukan pada penelitian ini, maka diperoleh kesimpulan sebagai berikut:

1. Kontribusi retribusi sampah terhadap PAD masih kecil dan justru cenderung menurun. Tahun 2010 kontribusi sebesar 1,2 persen tetapi menjadi 0,5 persen pada tahun 2016 sehingga masuk dalam kriteria sangat kurang. Terdapat beberapa kendala yang menyebabkan retribusi sampah rumah tangga kecil dan bahkan tidak pernah mencapai target yaitu tarif yang rendah, keterbatasan SDM, keterbatasan sarana prasarana dan rendahnya kesadaran masyarakat.

2. Sebanyak 120 responden yang membayar retribusi sampah rumah tangga diperoleh rata-rata WTP sebesar Rp35.000 per rumah tangga. Apabila disimulasikan dengan jumlah rumah tangga tahun 2014 sebanyak 682.878 rumah tangga, maka potensi ekonomi sesuai total WTP adalah Rp23,9 miliar per bulan atau Rp286,8 miliar per tahun. Hasil analisis regresi menunjukkan bahwa variabel bebas yang berpengaruh terhadap nilai WTP pada alpha 5 persen adalah kategori rumah dengan koefisien 0,283 dan frekuensi sampah diangkut dengan nilai koefisien sebesar $-0,110$ serta 0,268 nilai koefisien biaya lain pada Adjusted R-Square 70,2 persen. Sedangkan untuk tingkat pendapatan tidak berpengaruh terhadap nilai WTP. Variabel bebas secara keseluruhan menunjukkan nilai probabilitas sebesar 0,000 artinya bahwa tolak $\mathrm{H} 0$ atau minimal terdapat variabel bebas yang 
berpengaruh terhadap WTP dan dapat disimpulkan bahwa secara simultan variabel bebas berpengaruh terhadap WTP.

3. Prioritas Strategi berdasarkan AHP yaitu: 1) Meningkatkan sarana dan prasarana; 2) Revisi Perda mengenai skema tarif; 3) Meningkatkan kinerja SDM dan pelayanan; 4) Penyuluhan dan penegakan hukum; 5) Insentif dan disinsentif pengurangan sampah.

\section{DAFTAR PUSTAKA}

Annisa S, Kadir H, Mardiana. 2015. Analisis Willingness to Pay (WTP) Sampah Rumah Tangga (Studi Kasus Perumnas Kelurahan Simpang Baru Panam Pekanbaru). Jurnal JOM FEKOM, Vol. 2, No. 1: 1-16.

[Bapenda Kota Bekasi] Badan Perencanaan dan Pembangunan Daerah Kota Bekasi. 2016. Laporan Target dan Realisasi Pendapatan Daerah Kota Bekasi. Bekasi (ID). Bapenda Kota Bekasi.

[BPS Jawa Barat] Badan Pusat Statistik Jawa Barat. 2016. Jawa Barat Dalam Angka. BPS Jawa Barat.

Falatehan AF. 2016. Analytical Hierarchy Process: Teknik Pengambilan Keputusan untuk Pembangunan Daerah. Yogyakarta (ID): Indonesia Pustaka.

Halim A. 2004. Manajemen Keuangan Daerah. Yogyakarta (ID): UPP AMP YKPN.

Jaya IN, Budhi MKS, Marhaeni AAIN. 2014. Faktor- Faktor Yang Mempengaruhi Penerimaan Retribusi Sampah di Kabupaten Badung. Jurnal Buletin Studi Ekonomi, Vol. 19, No. 2: 128-135.
Kamalludin. 2013. Implementasi Kebijakan Retribusi Sampah di Kelurahan Gadang Kecamatan Sukun Kota Malang. Jurnal Reformasi. Vol. 3, No. 1: 32-41.

[Pemkot Bekasi] Pemerintah Kota Bekasi. 2005. Peraturan Daerah Kota Bekasi Nomor 07 Tahun 2005 tentang Retribusi Pelayanan Kebersihan.

[Pemkot Bekasi] Pemerintah Kota Bekasi. 2011. Peraturan Daerah Kota Bekasi Nomor 15 Tahun 2011 tentang Pengelolaan Sampah di Kota Bekasi.

[Pemkot Bekasi] Pemerintah Kota Bekasi. 2012. Peraturan Daerah Kota Bekasi Nomor 09 Tahun 2012 tentang Retribusi Daerah.

Rizal M. 2011. Analisis Pengelolaan Sampah Perkotaan (Studi Kasus pada Kelurahan Boya Kecamatan Banawa Kabupaten Donggala). Jurnal Smartek, Vol. 9, No. 2: 155172.

Sjafrizal. 2008. Ekonomi Regional, Teori dan Aplikasi. Baduose Media. Cetakan Pertama. Padang.

Tasrin K, Amalia S. 2014. Evaluasi Kinerja Pelayanan Persampahan di Wilayah Metropolitan Bandung Raya. Jurnal Borneo Administrator, Vol. 10, No. 1: 3558.

[UU] Undang-undang Nomor 22 Tahun 1999 tentang Pemerintahan Daerah.

[UU] Undang-undang Nomor 18 Tahun 2008 tentang Pengelolaan Sampah.

Yasniva, Hamzah A, Syahnur S. 2013. Analisis Kontribusi Penerimaan Retribusi Pelayanan Persampahan/Kebersihan terhadap Pendapatan Asli Daerah (PAD) Kota Banda Aceh. Jurnal Ilmu Ekonomi. Vol. 1, No. 4: 49-58. 


\section{Lampiran 1 Rencana Program dan Kegiatan tahun 2018-2022}

\begin{tabular}{|c|c|c|c|c|c|c|c|c|c|}
\hline \multirow{2}{*}{ No. } & \multirow{2}{*}{ Stategi } & \multirow{2}{*}{ Program } & \multirow{2}{*}{ Kegiatan } & \multirow{2}{*}{$\begin{array}{c}\text { Instansi/Lembaga } \\
\text { Terkait }\end{array}$} & \multicolumn{5}{|c|}{ Tahun Pelaksanaan } \\
\hline & & & & & 18 & 19 & 20 & 21 & 22 \\
\hline 1 & $\begin{array}{l}\text { Meningkatkan sarana dan } \\
\text { prasarana }\end{array}$ & $\begin{array}{l}\text { - Perluasan lahan Tempat } \\
\text { Pembuangan Akhir (TPA) } \\
\text { - Optimalisasi dan penambahan } \\
\text { alat angkut } \\
\text { - Penggunaan teknologi }\end{array}$ & $\begin{array}{l}\text { - Pembelian lahan tambahan } \\
\text { - Sistem pembayaran online } \\
\text { - Penambahan kendaraan angkut } \\
\text { - Penerapan teknologi baru }\end{array}$ & $\begin{array}{l}\text { Bapenda, Dinas } \\
\text { Lingkungan Hidup }\end{array}$ & $\begin{array}{l}\sqrt{ } \\
\sqrt{ } \\
\sqrt{ }\end{array}$ & $\sqrt{ }$ & $\begin{array}{l}\sqrt{ } \\
\sqrt{ }\end{array}$ & $\sqrt{ }$ & $\begin{array}{l}\sqrt{ } \\
\sqrt{ } \\
\sqrt{ }\end{array}$ \\
\hline 2 & $\begin{array}{l}\text { Revisi Perda mengenai } \\
\text { skema tarif }\end{array}$ & $\begin{array}{l}\text { Pengesahan Perda baru } \\
\text { mengenai struktur tarif }\end{array}$ & $\begin{array}{l}\text { - Penyusunan tarif baru } \\
\text { - Pengajuan rancangan Perda } \\
\text { - Pengesahan Perda }\end{array}$ & $\begin{array}{l}\text { Bapenda, Dinas } \\
\text { Lingkungan } \\
\text { Hidup, DPRD }\end{array}$ & $\begin{array}{l}\sqrt{ } \\
\sqrt{ } \\
\sqrt{ }\end{array}$ & & & & \\
\hline 3 & $\begin{array}{l}\text { Meningkatkan kinerja } \\
\text { SDM dan pelayanan }\end{array}$ & $\begin{array}{l}\text { - Peningkatan kualitas SDM } \\
\text { - Peningkatan layanan }\end{array}$ & $\begin{array}{l}\text { Penambahan SDM } \\
\text { - Pelatihan dan diklat } \\
\text { - Penerapan Sistem reward and punishment } \\
\text { - Peningkatan persentase pengangkutan }\end{array}$ & $\begin{array}{l}\text { Bapenda, Dinas } \\
\text { Lingkungan Hidup }\end{array}$ & $\begin{array}{l}\sqrt{ } \\
\sqrt{ } \\
\sqrt{ } \\
\sqrt{ }\end{array}$ & $\sqrt{ }$ & $\begin{array}{l}\sqrt{ } \\
\sqrt{ } \\
\sqrt{ } \\
\sqrt{ }\end{array}$ & $\begin{array}{l}\sqrt{ } \\
\sqrt{ }\end{array}$ & $\begin{array}{l}\sqrt{ } \\
\sqrt{ } \\
\sqrt{ } \\
\sqrt{ }\end{array}$ \\
\hline 4 & $\begin{array}{l}\text { Penyuluhan dan penegakan } \\
\text { hukum }\end{array}$ & $\begin{array}{l}\text { - Penyuluhan kepada } \\
\text { masyarakat } \\
\text { - Penegakan hukum }\end{array}$ & $\begin{array}{l}\text { - Sosialisasi UU dan Perda tentang sampah } \\
\text { - Pelatihan pengolahan sampah skala rumah } \\
\text { tangga } \\
\text { - Pembentukan satgas pengawas sampah liar }\end{array}$ & $\begin{array}{l}\text { Bapenda, Dinas } \\
\text { Lingkungan } \\
\text { Hidup, masyarakat }\end{array}$ & $\begin{array}{l}\sqrt{ } \\
\sqrt{ }\end{array}$ & $\begin{array}{l}\sqrt{ } \\
\sqrt{ }\end{array}$ & $\begin{array}{l}\sqrt{ } \\
\sqrt{ }\end{array}$ & $\begin{array}{l}\sqrt{ } \\
\sqrt{ }\end{array}$ & $\begin{array}{l}\sqrt{ } \\
\sqrt{ }\end{array}$ \\
\hline 5 & $\begin{array}{l}\text { Insentif dan disinsentif } \\
\text { pengurangan sampah }\end{array}$ & $\begin{array}{l}\text { - Insentif pengurangan sampah } \\
\text { - Disinsentif pengurangan } \\
\text { sampah }\end{array}$ & $\begin{array}{l}\text { Pemberian penghargaan kepada inovator } \\
\text { pengelola sampah } \\
\text { - Pemberian denda terhadap pelanggar } \\
\text { penanganan sampah }\end{array}$ & $\begin{array}{l}\text { Bapenda, Dinas } \\
\text { Lingkungan } \\
\text { Hidup, }\end{array}$ & $\sqrt{ }$ & $\sqrt{ }$ & $\sqrt{ }$ & $\sqrt{ }$ & $\begin{array}{l}\sqrt{ } \\
\sqrt{ }\end{array}$ \\
\hline
\end{tabular}

